\title{
Seedborne Infection of Pyrethrum by Phoma ligulicola
}

Sarah J. Pethybridge, Frank Hay, and Suzanne Jones, Tasmanian Institute of Agricultural Research (TIAR), University of Tasmania, P.O. Box 3523, Burnie, Tasmania, 7320, Australia; Calum Wilson, TIAR, University of Tasmania, New Town Research Laboratories, 13 St. Johns Ave., New Town, Tasmania, 7008, Australia; and Tim Groom, Botanical Resources Australia Pty. Ltd., 44-46 Industrial Drive, Ulverstone, Tasmania, 7315, Australia

\begin{abstract}
Pethybridge, S. J., Hay, F., Jones, S., Wilson, C., and Groom, T. 2006. Seedborne infection of pyrethrum by Phoma ligulicola. Plant Dis. 90:891-897.

The incidence of Phoma ligulicola in Tasmanian pyrethrum seed and methods of managing seedborne mycoflora were determined. Fourteen different fungi were regularly isolated from seed, including Alternaria tenuissima, Stemphylium botryosum, and P. ligulicola, which have been documented as pathogens of pyrethrum. Comparisons between the incidence of these fungi from seed surface-sterilized with sodium hypochlorite and nontreated seed indicated they occurred both within and on the outside of the seed. A polymerase chain reaction (PCR) test for the detection of $P$. ligulicola was also developed, with a detection limit of $800 \mathrm{fg}$ of fungal DNA. The assay detected infested seed lots down to an incidence of $0.5 \%$. Reliable amplification of the target DNA was achieved with the addition of bovine serum albumin to reduce the influence of inhibitors from pyrethrum seed. Agar plate tests and PCR demonstrated variability with pyrethrum cultivars in the presence and viability of $P$. ligulicola in seed. Effective management strategies for the reduction of seedborne $P$. ligulicola included the regular use of fungicides for reducing foliar disease intensity in the seed fields prior to harvest. Seed treatments with fludioxonil and thiabendazole/thiram also significantly reduced the incidence of seedborne P. ligulicola and increased seed germination and seedling survival.
\end{abstract}

Additional keywords: seedborne pathogen, Tanacetum cinerariaefolium

Ray blight, caused by Phoma ligulicola, is a major threat to production of pyrethrum (25) and chrysanthemum $(3,4)$. The disease is found in pyrethrum-producing regions such as East Africa (30), Papua New Guinea (31), and Tasmania, Australia $(22,27)$. Epidemics in Tasmanian pyrethrum fields occur annually in early spring. Symptoms range from necrotic spots on leaves and lesions on stems (23), to flower and bud blight $(23,27)$. If infection of the developing flowering stem is not managed by the strategic use of fungicides in spring, the disease can lead to complete loss of yield and early termination of fields $(23,25)$.

In chrysanthemum, inoculum sources can include alternative Compositae hosts (9), pseudosclerotia and conidia within the soil (6), infected cuttings (8), and airborne ascospores (3). Soilborne inoculum of $P$. ligulicola causing disease in chrysanthemum is mildly pathogenic to leaves or stems of globe artichoke (Cynara scolymus L.), rudbeckia (Rudbeckia hirta L.), zinnia

Corresponding author: S. J. Pethybridge

E-mail: sarah_jp@utas.edu.au

Accepted for publication 10 February 2006.

DOI: 10.1094/PD-90-0891

(C) 2006 The American Phytopathological Society
(Zinnia elegans L.), sunflower (Helianthus annuus L.), and dahlia (Dahlia variabilis Desf.), but severely pathogenic to lettuce (Lactuca sativa var. crispa L.), suggesting chrysanthemum crops should be geographically separated from these crops and avoided in their rotations (9). In rotations with nonsusceptible hosts, the inoculum contribution of pseudosclerotia is probably minimal, as their survival in natural soil ( $<30$ weeks) and compost ( $<8$ weeks) is limited (6). Numbers and viability of conidia also decline rapidly in natural soil (6). However, the pathogen-free status of the planting material is of paramount importance in reducing the probability of disease within commercial chrysanthemum crops. For example, symptomless infected cuttings were considered the major means of spread of this disease throughout the United States (4). Symptomless surface colonization of cuttings and roots by $P$. ligulicola were demonstrated from nonsterile soil where the fungus remained viable as an epiphyte for at least 12 weeks. These studies also demonstrated epiphytic colonization of 12 other ornamental species, including pyrethrum, but for no more than 8 weeks (8).

In contrast to chrysanthemum, little knowledge exists regarding the inoculum sources for ray blight disease in pyrethrum. The contribution of soilborne inoculum such as pseudosclerotia to the epidemic is unknown. However, rotations between pyrethrum in the same field are generally at least 3 years, suggesting that soilborne inoculum contributes to the epidemic only minimally. Pyrethrum fields in Tasmania are not generally within the same geographic region as ornamental production, and therefore are not as likely to act as alternative hosts. The presence of the teleomorph, Didymella ligulicola, has not yet been confirmed in Tasmania, suggesting minimal involvement of ascospores which could contribute to long-distance dispersal $(29,35)$. Vegetative propagation by splitting mother plants into several propagules, which may contain infected cuttings, has been used for field establishment in the past. Seed has become the primary means of propagation since 1999, and anecdotal evidence has suggested that seed may act as an inoculum source.

The objectives of this study were to: (i) characterize the mycoflora associated with pyrethrum seed; (ii) develop a polymerase chain reaction (PCR) test for the detection of seedborne P. ligulicola; (iii) quantify the incidence and viability of $P$. ligulicola in pyrethrum seed; (iv) examine the efficacy of different fungicide seed treatments for the reduction of seedborne $P$. ligulicola; and (v) quantify the relationship between foliar disease intensity and seedborne infection by P. ligulicola.

\section{MATERIALS AND METHODS}

Mycoflora of pyrethrum seeds. The mycoflora from commercial pyrethrum seed fields harvested from 1999 to 2004 were assessed by plate tests at a maximum of 30 days after harvest. Samples of harvested seed were stored in a paper bag at $4^{\circ} \mathrm{C}$. Two hundred arbitrarily selected seeds from each field were surfacesterilized in $1 \%$ sodium hypochlorite for 2 min, rinsed in sterile distilled water three times, and placed on $2 \%$ water agar (WA) in petri dishes. Ten seeds were placed on each petri dish and incubated in the dark at $20^{\circ} \mathrm{C}$. A further 10 non-surface-sterilized seeds were placed directly on WA in each of 20 petri dishes. Fungi were identified based on morphological characteristics after 21 days incubation using standard mycological keys (5). The presence of $P$. ligulicola was confirmed by subculturing hyphal tips to potato dextrose (Amyl Laboratories, Melbourne, Australia), malt extract (malt extract-oxoid L39 and oxoid 
agar no. 1), and oatmeal agars for identification $(7,29,34)$.

Detection of $\boldsymbol{P}$. ligulicola in pyrethrum seed by PCR. The efficiency of three methods of DNA extraction from pyrethrum seed for the detection of $P$. ligulicola using a PCR test previously described for detection from mycelium were tested (26). Five seed lots were created by mixing $190,95,45,20$, and 10 seeds from a commercially harvested cultivar containing $21 \%$ of seeds infected with P. ligulicola, determined by repeated plate tests, and made up to 380 seeds with a commercially harvested seed lot of the same cultivar from which P. ligulicola was not detected. These gave estimated final incidences of $10.5,5.25,2.5,1.1$, and $0.5 \%$, respectively. Four replicates of each seed lot were prepared. In the first extraction method (method 1), approximately $100 \mathrm{mg}$ of seed was ground to a powder using a mortar and pestle with liquid nitrogen, and DNA was extracted using the DNeasy Plant Mini Kit (Qiagen, Hilden, Germany) following the manufacturer's protocol. In the second extraction method (method 2), the entire seed sample was ground to a fine powder in a seed mill (Glen Creston Ltd., UK) and $100 \mathrm{mg}$ used for DNA extraction using the DNeasy Plant Mini Kit (Qiagen). Final elutions of DNA from the columns using both these methods were conducted with $100 \mu \mathrm{l}$ of standard elution buffer. In the third and fourth methods, each seed lot was shaken in $50 \mathrm{ml}$ of CTAB buffer for $2.5 \mathrm{~h}$ at room temperature. Two milliliters of the resultant solution was then removed for DNA extraction using the DNeasy Plant Mini Kit (Qiagen) (method 3) or purification with an equal volume of phenol:chloroform:isoamyl alcohol (25:24:1) (method 4). For the latter method, an ethanol precipitation was then conducted and resultant DNA collected in $10 \mu \mathrm{l}$ of TE buffer. The presence of DNA extracted from all methods was verified by separation on a $1 \%$ agarose gel in $1 \times$ TAE (40 $\mathrm{mM}$ Tris-acetate, $1 \mathrm{mM}$ EDTA, $\mathrm{pH}$ 8.0) stained with ethidium bromide $(0.5$ $\mathrm{mg} /$ liter) and visualized under UV light. The concentrations of extracted DNA were assessed by comparison to molecular mass standards (Bio-Rad Laboratories, Hercu- les, CA). Purity was judged by the extraction of DNA in one or multiple bands.

Detection of P. ligulicola from DNA extractions from pyrethrum seed used the primer pairs (PL1/PL2) previously developed to amplify a 230-bp product within the ITS region (26). In brief, the PCR was performed in $50-\mu \mathrm{l}$ reactions containing $2.5 \mathrm{mM} \mathrm{MgCl}_{2}, 1 \mathrm{mmol}$ deoxynucleoside triphosphate, $0.5 \mu \mathrm{mol}$ of each oligonucleotide primer, and 1 unit Taq polymerase (Qiagen) in 1× PCR Buffer (Qiagen). Optimization of the PCR conditions to minimize PCR inhibition by plant extracts was conducted with different concentrations (1, $3,5,10,15$, and $20 \%$ ) of bovine serum albumin (BSA) (Roche Diagnostics, Alameda, CA). One microliter containing 20 to $25 \mathrm{ng}$ of DNA was used as the template for each reaction. PCR reactions were conducted with a GeneAmp PCR System 2400 (Perkin Elmer, Norwalk, CT) thermocycler using the following conditions: 5 min at $94^{\circ} \mathrm{C}$ for initial denaturation followed by 35 cycles of $30 \mathrm{~s}$ of denaturation at $94^{\circ} \mathrm{C}, 1 \mathrm{~min}$ of annealing at $56^{\circ} \mathrm{C}$, and 2 min extension at $72^{\circ} \mathrm{C}$. Reactions concluded with a final extension at $72^{\circ} \mathrm{C}$ for 10 min. PCR products were visualized in a $2 \%$ agarose gel (ICN Biochemicals, Ohio) and $1 \times$ TBE (40 mM Tris-borate, $1 \mathrm{mM}$ EDTA, pH 8.0) buffer containing ethidium bromide under UV light.

The sensitivity of the PCR test was examined using three different methods. The first method used a dilution series of $P$. ligulicola genomic DNA from isolate DZ 62547 ranging from $8 \mathrm{ng} / \mu \mathrm{l}$ to $8 \mathrm{fg} / \mu \mathrm{l}$, diluted in sterile distilled water. Concentrations were determined by comparison to a molecular mass standard (Bio-Rad Laboratories) on a $2 \%$ agarose gel (described above). Each dilution was replicated and the PCR was conducted twice. The two subsequent methods examined the sensitivity of the PCR to detect P. ligulicola when pyrethrum seed DNA was also present in the extractions. To test whether the PCR could detect one infected seed in a 100-mg sample of healthy seeds, 20 replicates of seed lot mixtures were produced containing one seed randomly selected from a highly infected seed lot $(65 \%)$ and the remaining from a seed lot where $P$. liguli-

Table 1. List of fungicides and active ingredients used in trials

\begin{tabular}{|c|c|c|}
\hline Product & Active ingredient & Supplier \\
\hline Amistar WG & $500 \mathrm{~g} / \mathrm{kg}$ azoxystrobin & Syngenta Australia \\
\hline Bravo 720 & $720 \mathrm{~g} /$ liter chlorothalonil & Syngenta Australia \\
\hline Sporekill & $120 \mathrm{~g} /$ liter didecyldimethyl-ammonium chloride & Lefroy Valley Australia \\
\hline Thiram & $800 \mathrm{~g} / \mathrm{kg}$ thiram & $\begin{array}{l}\text { Barmac Industries Pty. Ltd., } \\
\text { Queensland, Australia }\end{array}$ \\
\hline Tecto SC & $500 \mathrm{~g} /$ liter thiabendazole & Syngenta Australia \\
\hline Maxim $100 \mathrm{FS}$ & $100 \mathrm{~g} /$ liter fludioxonil & Syngenta Australia \\
\hline Walabi SC & $\begin{array}{l}375 \mathrm{~g} / \text { liter chlorothalonil and } \\
150 \mathrm{~g} / \text { liter pyrimethanil }\end{array}$ & Bayer Crop Science Australia \\
\hline BAS516 & $\begin{array}{l}100 \mathrm{~g} / \text { liter pyraclostrobin and } \\
200 \mathrm{~g} / \text { liter boscalid }\end{array}$ & NuFarm Australia \\
\hline Stroby WG & $500 \mathrm{~g} / \mathrm{kg}$ kresoxim-methyl & BASF Australia Limited \\
\hline
\end{tabular}

cola was not detected by repeated plate tests or PCR. DNA was extracted from these seed lots using method 1 . The detection limit was further examined with the DNA extracted by method 1 from the range of replicate incidence batches (10.5 to $0.5 \%$ ), described above to examine the reliability of DNA extraction techniques.

Incidence of $P$. ligulicola in pyrethrum seed. The incidence of $P$. ligulicola in commercial seed harvested from fields in 1995 to 2003 was assessed by plate tests and PCR in 2003. Plate tests used the techniques described above to characterize the spectrum of mycoflora associated with pyrethrum seed and hence determined if the P. ligulicola detected by PCR was viable. Incidence of $P$. ligulicola in seed from fields harvested in 1999 to 2004, in which previous information was available on the incidence of $P$. ligulicola directly following harvest, was compared with the incidence following testing in 2004.

DNA was extracted from 10 replicates of $100 \mathrm{mg}$ of seed following method 1 , and PCR detection of $P$. ligulicola was undertaken using a final concentration of $10 \%$ BSA within the reaction mixture described above. The incidence of $P$. ligulicola within the seed $(\%)$ was estimated from the number of bulk samples in which $P$. ligulicola was detected (e.g., 1/10 bulk samples testing positive $=0.14 \%$ estimated incidence; $2 / 10=0.29 \% ; 3 / 10=0.47 \%$; $4 / 10=0.68 \% ; 5 / 10=0.92 \% ; 6 / 10=$ $1.21 \% ; 7 / 10=1.59 \% ; 8 / 10=2.12 \% ; 9 / 10$ $=3.02 \% ; 10 / 10=100 \%)(11)$.

Relationship between foliar disease intensity and incidence of seedborne $\boldsymbol{P}$. ligulicola. The relationship between foliar disease intensity prior to harvest and the incidence of seedborne $P$. ligulicola was described. Epidemics of different intensities were generated by the application of fungicides of varying efficacy within a commercial field approaching its first harvest at Table Cape (UTM: 55 G 394130 5658008). Fungicide treatments were: chlorothalonil (1,440 g a.i./ha), azoxystrobin (250 g a.i./ha), kresoxim-methyl (150 g a.i./ha), boscalid and pyraclostrobin (200 g a.i./ha and $400 \mathrm{~g}$ a.i./ha, respectively), chlorothalonil and pyrimethanil (750 g a.i./ha and $300 \mathrm{~g}$ a.i./ha), and a nontreated control. Fungicide details are listed (Table 1). Fungicides were applied three times from early spring on $24 \mathrm{Au}$ gust, 12 September, and 3 October 2004. Plots were $19.2 \mathrm{~m}^{2}(3.2 \times 6 \mathrm{~m})$ and separated by $1-\mathrm{m}$ buffers to minimize spray drift. Fungicides were applied with a gasoline-driven Solo 432 backpack sprayer with a 1.6-m boom fitted with hollow cone nozzles spaced at $40-\mathrm{cm}$ intervals, delivering 300 liters/ha.

Foliar disease intensity was measured on 20 August (prior to fungicide applications), 13 October, and 18 November. Within each plot, 20 flowering stems were systematically selected along a diagonal 
transect. Each stem was removed from the base of the plant stored at $4^{\circ} \mathrm{C}$ until assessment within $48 \mathrm{~h}$. Defoliation severity was defined as the height to defoliation (leaves either completely necrotic or abscised) divided by the total stem height $x$ 100. On each flowering stem, the number of diseased and healthy flowers and/or buds was also counted. This enabled the calculation of the "incidence of flowering stems with ray blight" defined as the number of flowering stems with any diseased flowers and/or buds divided by the total number of flowering stems $\times 100$, and the "incidence of flowers with ray blight" defined as the number of diseased flowers and/or buds divided by the total number of flowers on each stem $\times 100$.

On 15 February 2005, seed was hand harvested from each plot, air-dried, and cleaned. The incidence of viable $P$. ligulicola in seed from each plot was assessed in plate tests following storage at $4{ }^{\circ} \mathrm{C}$ in a paper bag for no longer than 28 days. Two hundred arbitrarily selected seeds from each crop were placed directly on WA (10 seeds per plate) and incubated in the dark at $20^{\circ} \mathrm{C}$. Fungi were identified 21 days later based on morphological characteristics using standard mycological keys
$(5,29)$. Linear regression analyses were conducted using Genstat 8, Version 1 (Adept Scientific Inc., Bethesda, MD). Goodness-of-fit between disease intensity in October and November, and the incidence of seedborne $P$. ligulicola, was

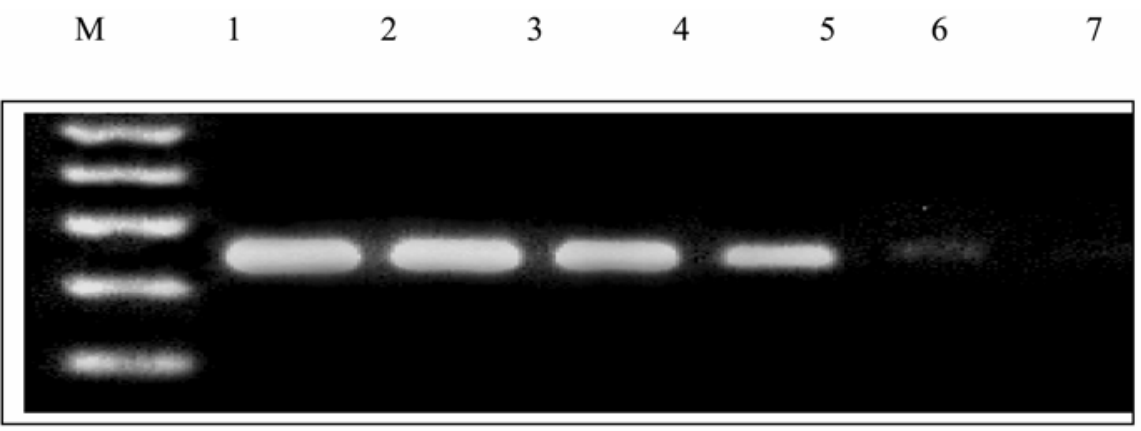

Fig. 1. Detection limit of the Phoma ligulicola primer pair (PL1/PL2). The primer pair was used in the polymerase chain reaction with serial dilutions of $P$. ligulicola total genomic DNA. Lanes 1 to 7 contain $8 \mathrm{ng}, 800 \mathrm{pg}, 80 \mathrm{pg}, 8 \mathrm{pg}, 800 \mathrm{fg}, 80 \mathrm{fg}$, and $8 \mathrm{fg}$ of total genomic DNA, respectively. Lane M contains the 100-bp ladder (Geneworks, Adelaide, Australia). Uppermost band $=500 \mathrm{bp}$.

Table 2. Incidence (\%) of fungi isolated from surface-sterilized or nontreated commercial pyrethrum seeds harvested between 2000 and 2005

\begin{tabular}{|c|c|c|c|c|c|c|c|c|c|c|}
\hline \multirow[b]{2}{*}{$\begin{array}{l}\text { Cultivar } \\
\text { (line) }\end{array}$} & \multirow[b]{2}{*}{ Sterilization } & \multirow[b]{2}{*}{ Year } & \multicolumn{8}{|c|}{ Incidence (\%) } \\
\hline & & & $\begin{array}{c}\text { Aureobasidium } \\
\text { pullulans }\end{array}$ & $\begin{array}{c}\text { Alternaria } \\
\text { spp. }^{\mathbf{y}}\end{array}$ & $\begin{array}{c}\text { Cladosporium } \\
\text { spp. }^{y}\end{array}$ & $\begin{array}{l}\text { Stemphylium } \\
\text { botryosum }\end{array}$ & $\begin{array}{c}\text { Ulocladium } \\
\text { atrum }\end{array}$ & $\begin{array}{c}\text { Phoma } \\
\text { ligulicola }\end{array}$ & $\begin{array}{c}\text { Microsphaeropsis } \\
\text { sp. }\end{array}$ & Others $^{z}$ \\
\hline $1-1$ & None & 2000 & 80 & 45 & 45 & 6 & 1 & 22 & 0 & 3 \\
\hline $1-1$ & Surface & 2000 & 60 & 39 & 22 & 8 & 3 & 17 & 0 & 5 \\
\hline $2-1$ & None & 2000 & 69 & 33 & 18 & 4 & 3 & 19 & 3 & 7 \\
\hline $2-1$ & Surface & 2000 & 74 & 35 & 12 & 7 & 2 & 18 & 2 & 2 \\
\hline $3-1$ & None & 2000 & 80 & 27 & 8 & 1 & 6 & 12 & 0 & 6 \\
\hline $3-1$ & Surface & 2000 & 75 & 29 & 5 & 3 & 4 & 9 & 1 & 4 \\
\hline 4 & None & 2000 & 74 & 16 & 6 & 0 & 1 & 7 & 0 & 9 \\
\hline 4 & Surface & 2000 & 70 & 15 & 8 & 1 & 1 & 8 & 0 & 5 \\
\hline $1-1$ & None & 2001 & 60 & 90 & 14 & 4 & 4 & 4 & 2 & 0 \\
\hline $1-1$ & Surface & 2001 & 45 & 84 & 8 & 2 & 0 & 4 & 1 & 0 \\
\hline $1-2$ & None & 2001 & 72 & 54 & 30 & 0 & 6 & 2 & 0 & 4 \\
\hline $1-2$ & Surface & 2001 & 52 & 25 & 16 & 0 & 0 & 1 & 0 & 6 \\
\hline $1-3$ & None & 2001 & 78 & 84 & 30 & 0 & 6 & 2 & 0 & 4 \\
\hline $1-3$ & Surface & 2001 & 59 & 41 & 16 & 0 & 1 & 2 & 0 & 2 \\
\hline $2-1$ & None & 2001 & 65 & 74 & 30 & 0 & 2 & 4 & 2 & 0 \\
\hline $2-1$ & Surface & 2001 & 42 & 43 & 18 & 0 & 0 & 4 & 4 & 0 \\
\hline $2-2$ & None & 2001 & 74 & 64 & 32 & 0 & 4 & 1 & 0 & 1 \\
\hline $2-2$ & Surface & 2001 & 23 & 38 & 19 & 0 & 2 & 0 & 0 & 2 \\
\hline $3-1$ & None & 2001 & 64 & 92 & 22 & 0 & 2 & 1 & 0 & 2 \\
\hline $3-1$ & Surface & 2001 & 52 & 34 & 10 & 0 & 0 & 0 & 0 & 1 \\
\hline $3-2$ & None & 2001 & 75 & 68 & 68 & 0 & 12 & 2.5 & 0 & 2 \\
\hline $3-2$ & Surface & 2001 & 63 & 12 & 35 & 0 & 1 & 0 & 0 & 1 \\
\hline $1-1$ & None & 2002 & 64 & 65 & 25 & 22 & 16 & 10 & 7.5 & 10 \\
\hline $1-1$ & Surface & 2002 & 58 & 41 & 18 & 18 & 5 & 4 & 6 & 8 \\
\hline $2-1$ & None & 2002 & 45 & 91 & 15 & 14.5 & 17 & 5 & 0 & 12 \\
\hline $2-1$ & Surface & 2002 & 23 & 76 & 10 & 8 & 2 & 3 & 0 & 7 \\
\hline $1-1$ & None & 2003 & 100 & 69 & 16 & 6 & 20 & 3 & 3 & 0 \\
\hline $1-1$ & Surface & 2003 & 60 & 43 & 8 & 0 & 2 & 1 & 2 & 2 \\
\hline $2-1$ & None & 2003 & 85 & 58 & 13 & 8 & 12 & 2 & 1 & 2 \\
\hline $2-1$ & Surface & 2003 & 74 & 38 & 5 & 1 & 4 & 4 & 1 & 0 \\
\hline 4 & None & 2003 & 100 & 24 & 6 & 0 & 1 & 0 & 0 & 0 \\
\hline 4 & Surface & 2003 & 81 & 14 & 4 & 0 & 0 & 0 & 0 & 0 \\
\hline 5 & None & 2003 & 100 & 10 & 14 & 0 & 10 & 0 & 0 & 0 \\
\hline 5 & Surface & 2003 & 74 & 0 & 0 & 0 & 2 & 0 & 0 & 0 \\
\hline $1-1$ & None & 2004 & 63 & 43 & 32 & 0 & 10 & 28 & 0 & 0 \\
\hline $1-1$ & Surface & 2004 & 41 & 12 & 12 & 0 & 1 & 12 & 0 & 0 \\
\hline $2-1$ & None & 2004 & 58 & 40 & 18 & 0 & 5 & 15 & 0 & 0 \\
\hline $2-1$ & Surface & 2004 & 34 & 22 & 6 & 0 & 0 & 10 & 0 & 0 \\
\hline $1-1$ & None & 2005 & 75 & 25 & 23 & 4 & 5 & 10 & 4 & 0 \\
\hline $1-1$ & Surface & 2005 & 64 & 15 & 4 & 9 & 0 & 7 & 3 & 0 \\
\hline $2-2$ & None & 2005 & 68 & 33 & 13 & 4 & 5 & 5 & 3 & 0 \\
\hline $2-2$ & Surface & 2005 & 46 & 29 & 7 & 11 & 1 & 0.5 & 2 & 0 \\
\hline
\end{tabular}

y Alternaria spp. include A. alternata and A. tenuissima; Cladosporium spp. include C. cladosporioides and C. herbarum.

${ }^{\mathrm{z}}$ Includes Acremonium sp., Phoma epicoccina, Fusarium spp., Penicillium italicum, Penicillium expansum, and other sterile fungi. 




Fig. 2. Detection of Phoma ligulicola from pyrethrum seed lots with varying incidence using polymerase chain reaction (PCR) with primer pair PL1/PL2. Lanes 1 to 12 show two independent DNA extractions from each seed lot with incidences of: lanes 1 and 2, 10.5\%; lanes 3 and 4, 5.25\%; lanes 5 and 6, 2.5\%; lanes 7 and $8,1.1 \%$; and lanes 9 and 10, $0.5 \%$. Lane 11 is a positive control showing the amplification of the approximately 230-bp PCR product from pyrethrum seed total genomic DNA. Lane 12 is a negative control containing pyrethrum seed DNA only. Lane M contains the 100-bp DNA ladder (Geneworks, Adelaide, Australia). Uppermost band $=500 \mathrm{bp}$.

Table 3. Incidence of Phoma ligulicola in pyrethrum seed lots harvested from 1995 to 2005 as determined by polymerase chain reaction (PCR) and plate tests either directly following harvest and/or in 2003

\begin{tabular}{|c|c|c|c|c|c|}
\hline \multirow[b]{2}{*}{$\begin{array}{l}\text { Cultivar } \\
\text { (line) }\end{array}$} & \multirow[b]{2}{*}{ Year } & \multicolumn{2}{|c|}{ PCR detection } & \multicolumn{2}{|c|}{ Incidence (\%) by plate tests } \\
\hline & & $\begin{array}{l}\text { Replicate extractions } \\
\text { with } P \text {. ligulicola } \\
\text { detected }(n=10)\end{array}$ & $\begin{array}{l}\text { Estimated } \\
\text { incidence }^{\mathrm{z}}\end{array}$ & $\begin{array}{c}\text { Directly } \\
\text { following } \\
\text { harvest }\end{array}$ & In 2003 \\
\hline $1-1$ & 1995 & 9 & 3.02 & - & 0 \\
\hline $1-2$ & 1995 & 9 & 3.02 & - & 0 \\
\hline $2-1$ & 1995 & 2 & 0.29 & - & 0 \\
\hline $3-1$ & 1995 & 0 & 0 & - & 0 \\
\hline $3-2$ & 1995 & 0 & 0 & - & 0 \\
\hline 4 & 1995 & 0 & 0 & - & 0 \\
\hline 5 & 1995 & 2 & 0.29 & - & 0 \\
\hline $6-1$ & 1995 & 0 & 0 & - & 0 \\
\hline $6-2$ & 1995 & 0 & 0 & - & 0 \\
\hline $1-1$ & 1996 & 10 & 100 & - & 0 \\
\hline $2-1$ & 1996 & 2 & 0.29 & - & 0 \\
\hline $3-2$ & 1996 & 0 & 0 & - & 0 \\
\hline 4 & 1996 & 0 & 0 & - & 0 \\
\hline $5-1$ & 1996 & 0 & 0 & - & 0 \\
\hline $1-1$ & 1997 & 9 & 3.02 & - & 0 \\
\hline $2-1$ & 1997 & 4 & 0.67 & - & 0 \\
\hline $3-2$ & 1997 & 0 & 0 & - & 0 \\
\hline $1-1$ & 1998 & 10 & 100 & - & 0 \\
\hline $1-2$ & 1998 & 5 & 0.92 & - & 0 \\
\hline $2-1$ & 1998 & 0 & 0 & - & 0 \\
\hline $3-1$ & 1998 & 0 & 0 & - & 0 \\
\hline 5 & 1998 & 4 & 0.67 & - & 0 \\
\hline $1-1$ & 1999 & 10 & 100 & - & 2 \\
\hline $1-2$ & 1999 & 10 & 100 & - & 0.5 \\
\hline $2-1$ & 1999 & 0 & 0 & - & 0 \\
\hline $3-1$ & 1999 & 0 & 0 & - & 0.5 \\
\hline 4 & 1999 & 4 & 0.67 & - & 0 \\
\hline $1-1$ & 2000 & 10 & 100 & 22 & 1 \\
\hline $2-1$ & 2000 & 10 & 10 & 19 & 0 \\
\hline $3-1$ & 2000 & 10 & 10 & 12 & 0 \\
\hline 4 & 2000 & 3 & 0.47 & 7 & 1 \\
\hline $1-1$ & 2001 & 8 & 2.12 & 4 & 6 \\
\hline $1-2$ & 2001 & 9 & 3.02 & 2 & 2 \\
\hline $1-3$ & 2001 & 2 & 0.29 & 2 & 1 \\
\hline $2-1$ & 2001 & 4 & 0.67 & 4 & 1 \\
\hline $2-2$ & 2001 & 0 & 0 & 1 & 0 \\
\hline $3-1$ & 2001 & 0 & 0 & 1 & 0 \\
\hline $3-2$ & 2001 & 2 & 0.29 & 2.5 & 0 \\
\hline $1-1$ & 2002 & 8 & 2.12 & 10 & 2.5 \\
\hline $2-1$ & 2002 & 9 & 3.02 & 5 & 1 \\
\hline $1-1$ & 2003 & 8 & 2.12 & 3 & - \\
\hline $2-1$ & 2003 & 0 & 0 & 2 & - \\
\hline 4 & 2003 & 0 & 0 & 0 & - \\
\hline 5 & 2003 & 0 & 0 & 0 & - \\
\hline $1-1$ & 2004 & 5 & 0.92 & 28 & - \\
\hline $2-1$ & 2004 & 2 & 0.29 & 15 & - \\
\hline $1-1$ & 2005 & 5 & 0.92 & 10 & - \\
\hline $2-2$ & 2005 & 2 & 0.29 & 5 & - \\
\hline
\end{tabular}

${ }^{\mathrm{z}}$ Incidence estimated based on the number of seed lot replications testing positive by PCR based on the maximum likelihood estimation (11). based on $R^{2}$, the standard error of the estimate of Y (SEEy), and visual inspection of residual plots. Precision of the model was assessed by the coefficient of variation $(\mathrm{CV})$, defined as the square root of the mean square error, divided by the grand mean of Y (20).

Effect of fungicides on the incidence of $P$. ligulicola, seed germination, and seedling survival. The efficacy of thiabendazole $(10 \mathrm{ml} / \mathrm{kg}$ seed $) /$ thiram $(5 \mathrm{~g} / \mathrm{kg}$ seed) was assessed in two replicated trials on three cultivars where the incidence of $P$. ligulicola in the nontreated seed varied between 12 and $21 \%$ as described by plate tests. Furthermore, the efficacy of didecyldimethyl-ammonium chloride (20 $\mathrm{ml} / \mathrm{kg}$ seed) and fludioxonil $(7 \mathrm{ml} / \mathrm{kg}$ seed) was assessed in another two replicated trials using one cultivar where $21 \%$ of nontreated seeds were infected with $P$. ligulicola as determined by plate tests. Fungicides were applied to approximately $3 \mathrm{~g}$ of seed. All fungicides and combined fungicide treatments (premixed) were applied as slurry in combination with wallpaper paste (Polycell Products, Australia). Fungicide slurries and seed were placed into a precoated sealed container and mixed for approximately $1 \mathrm{~min}$ to ensure total coverage then air-dried, prior to further testing within $48 \mathrm{~h}$.

Reductions in the incidence of $P$. ligulicola were assessed by plate tests. Ten seeds were directly placed on WA in petri dishes and incubated in the dark at $20^{\circ} \mathrm{C}$ for 21 days. Seed germination was assessed by placing 400 arbitrarily selected seeds on $90 \mathrm{~mm}$ Whatman no. 1 filter paper moistened with sterile distilled water in each of 10 sterile petri dishes, which were then sealed and incubated in the dark at $20^{\circ} \mathrm{C}$. Seeds germinated after 25 days were counted. Seedling survival was assessed by planting six replicates of 50 arbitrarily selected seeds into autoclaved $\left(121^{\circ} \mathrm{C}\right.$ for $30 \mathrm{~min}$ ) seed raising mixture in surfacesterilized trays. Trays were placed in a heated glasshouse $\left(20 \pm 4^{\circ} \mathrm{C}\right)$ and the number of seedlings counted 28 days after planting. The efficacy of fungicides on reducing the incidence of $P$. ligulicola, improving seed germination and seedling survival, compared with a nontreated control, was compared by analysis of variance using Genstat 8, Version 1 (Adept Scientific Inc.).

\section{RESULTS}

Mycoflora of pyrethrum seeds. Fourteen fungal species were regularly associated with pyrethrum seed, and often multiple species were found on individual seeds (Table 2). The most frequently isolated in both surface-sterilized and nonsterilized seed were Aureobasidium pullulans, Alternaria spp. (A. alternata and A. tenuissima), Cladosporium spp. (C. herbarum and $C$. cladosporioides), Stemphylium botryosum, Ulocladium atrum, P. ligulicola, and $\mathrm{Mi}$ - 
crosphaeropsis sp. with a mean incidence of $65,43,17,3,4,6$, and $1 \%$, respectively. Seed harvested in 2000 had a higher incidence of $P$. ligulicola in most cultivars. Less $P$. ligulicola occurred in seed harvested in 2001, which coincided with the implementation of a fungicide program for seed crops. Surface sterilization of seed reduced the incidence of $A$. pullulans, Alternaria spp., Cladosporium spp., $U$. atrum, and P. ligulicola. The incidence of Microsphaeropsis sp. was sporadic and not greatly affected by surface sterilization (Table 2).

Detection of $P$. ligulicola in pyrethrum seed by PCR. A 230-bp amplicon was generated by PCR from genomic DNA extracted from infected pyrethrum seed. Sensitivity tests using serial dilutions of $P$. ligulicola total genomic DNA allowed successful detection with as little as $800 \mathrm{fg}$ DNA (Fig. 1). Using DNA extraction methods 1 and 2, P. ligulicola was detected from infected seed lots down to an incidence of $0.5 \%$ (Fig. 2). Using the third extraction method, $P$. ligulicola was not detected at incidences less than $5.25 \%$, and at both 10.5 and $5.25 \%$, P. ligulicola was only detected in $50 \%$ of replicate samples. Furthermore, P. ligulicola was detected in $60 \%$ of replicate extractions from mixing one seed from a highly infected seed lot with seeds from a lot with no detectable $P$. ligulicola using extraction method 1 . The reliability of amplification was improved by the addition of $10 \%$ BSA (data not shown).

Incidence of $P$. ligulicola in pyrethrum seed. The incidence of seedborne $P$. ligulicola was quantified using PCR and viability assessed using plate tests (Table 3). Estimation of incidence of $P$. ligulicola based on results of PCR was useful when the incidence of $P$. ligulicola was low. However, using 10 replicates per seed lot, this test was not able to reliably estimate incidence between $3.02 \%$ (P. ligulicola detected in 9 of 10 replicates) and $100 \%$ ( $P$. ligulicola detected in all replicates). The incidence of $P$. ligulicola as assessed by plate tests directly following harvest was on average $1.4,2.9,8.9$, and 17.2 times greater in 2004 than in 2000, 2002 and 2005, 2001, and 2003, respectively. The incidence of seedborne $P$. ligulicola was also affected by cultivar, with cultivar 1 having at least 1.36 times more P. ligulicola than other cultivars.

Discrepancies were noted between the incidence of $P$. ligulicola as estimated by plate tests directly following harvest and following storage times of up to 3 years. For example, the incidence of $P$. ligulicola in "cultivar 1 , seedline 1 " seed declined from $22 \%$ in seed tested immediately after harvest in 2000 , to $1 \%$ following retesting in 2003 (Table 3). However, in seed harvested between 2001 and 2003, the low incidence of $P$. ligulicola made conclusions regarding survival in seed difficult
(Table 3). Greatly reduced viability of $P$. ligulicola following seed storage was also noted in seed harvested from 1995 to 1999, with plate tests failing to detect $P$. ligulicola in seed lots harvested prior to 1998, despite detection by PCR (Table 3). Irrespective of year of harvest, $P$. liguli- cola was detected by PCR in at least five of the 10 replicates of all cultivar 1 seed, while none was detected in cultivar 3 (Table 3).

Relationship between foliar disease intensity and incidence of seedborne $P$. ligulicola. Significant relationships be-
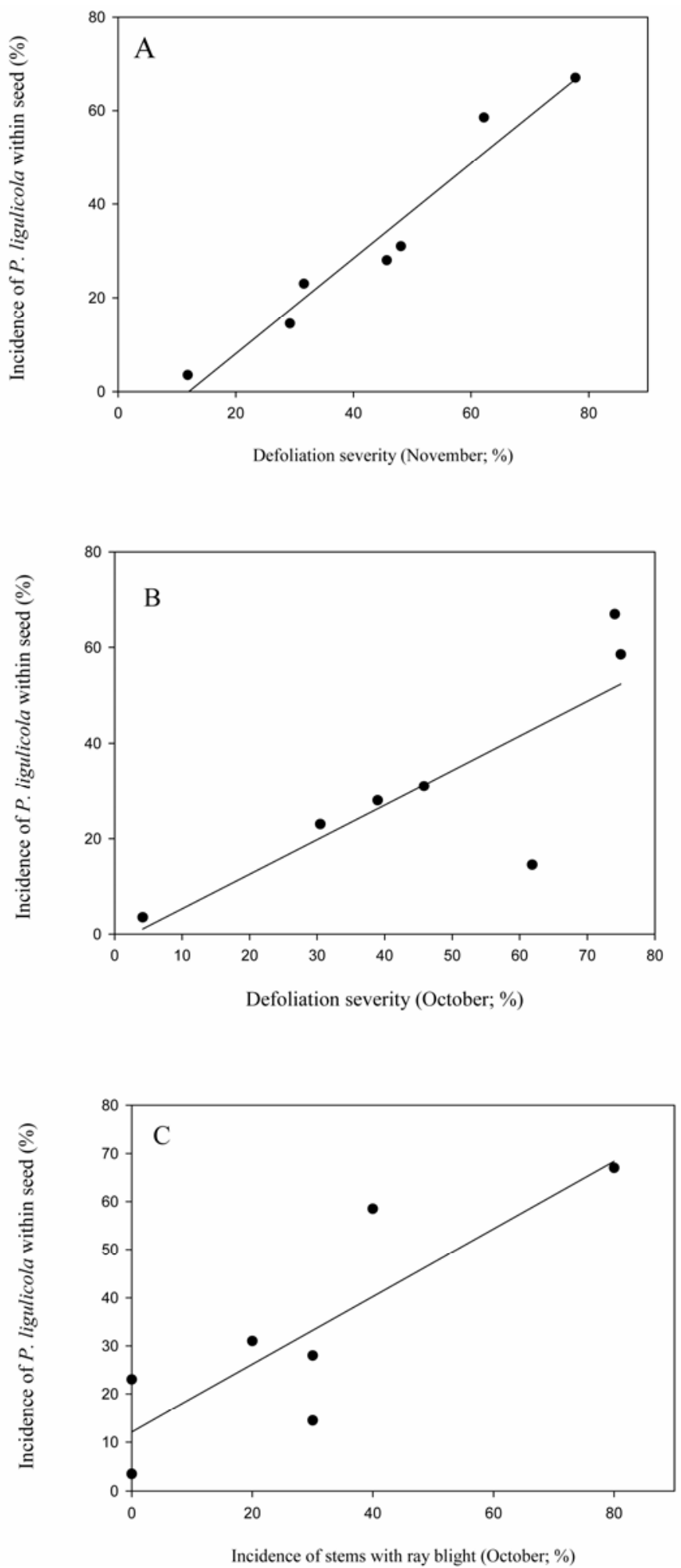

Fig. 3. Effect of foliar disease intensity on the incidence of Phoma ligulicola within pyrethrum seed when significant $(P<0.05)$ regression models were detected. A, Incidence of $P$. ligulicola within seed $(\%)=-12.19 \times$ defoliation severity in November $(\%)+1.01 ; R^{2}=0.98 ; \mathbf{B}$, Incidence of $P$. ligulicola within seed $(\%)=-1.95 \times$ defoliation severity in October $(\%)+0.72 ; R^{2}=0.89 ; \mathbf{C}$, Incidence of $P$. ligulicola within seed $(\%)=12.13 \times$ incidence of stems with ray blight in October $+0.67 ; R^{2}=0.91$. 
tween foliar disease intensity in October and November and the incidence of $P$. ligulicola within seed were detected (Fig. 3). Significant regressions $(P<0.05)$ were detected between the incidence of $P$. ligulicola within seed and defoliation severity in October and November and the incidence of stems with ray blight in October. The $R^{2}$ values for these significant models ranged from 0.89 and 0.98 . The best predictor of the incidence of $P$. ligulicola within seed was defoliation severity in November $\left(R^{2}=\right.$ 0.98). The slopes for these significant models ranged from 0.72 and 1.01, which indicated the incidence of $P$. ligulicola within seed increased from 0.72 to $1.01 \%$ with each $1 \%$ increase in disease intensity. SEEy indicated that using disease intensity to predict $P$. ligulicola incidence in seed had a standard error between 5.64 and $14.78 \%$. The coefficient of variation for the significant models ranged from 7.4 to $11.9 \%$ (Fig. 3).

Effect of fungicides on incidence of $P$. ligulicola, seed germination, and seedling survival. In all three cultivars of seed harvested in 2000, treatment of seed with thiabendazole and thiram significantly $(P<$ $0.001)$ reduced the incidence of viable $P$. ligulicola and increased seed germination $(P=0.021)$ and seedling survival $(P=$ $0.001)$ over nontreated seed. Application of thiabendazole and thiram reduced the incidence of viable $P$. ligulicola by 7.5 times, increased seed germination by 1.8 times, and increased seedling survival by 1.2 times (Table 4).

In cultivar 1, the effect of fludioxonil on the incidence of $P$. ligulicola, and seed germination and seedling survival, was not significantly different from that of thiabendazole and thiram (Table 4). Didecyldimethyl-ammonium chloride gave no significant reductions in the incidence of $P$. ligulicola and increases in seed germination or seedling survival compared with nontreated seed.

Table 4. Effect of thiabendazole/thiram in three cultivars (1, 2, and 3) and didecyldimethyl-ammonium chloride, fludioxonil, and thiabendazole/thiram in one cultivar (1) on incidence of Phoma ligulicola detected in plate tests, seed germination, and seedling survival

\begin{tabular}{llccc}
\hline Cultivar & Treatment & $\begin{array}{c}\text { Incidence of } \\
\text { P. ligulicola }(\%)\end{array}$ & $\begin{array}{c}\text { Seed } \\
\text { germination }(\%)\end{array}$ & $\begin{array}{c}\text { Seedling } \\
\text { survival (\%) }\end{array}$ \\
\hline 1 & Thiabendazole/thiram & $2 \mathrm{~b}$ & $85 \mathrm{a}$ & $51 \mathrm{a}$ \\
& Nontreated & $22 \mathrm{a}^{\mathrm{z}}$ & $45 \mathrm{~b}$ & $43 \mathrm{~b}$ \\
& LSD $(P)$ & $1.2(<0.001)$ & $5.4(0.002)$ & $2.9(<0.001)$ \\
2 & $3 \mathrm{~b}$ & $67 \mathrm{a}$ & $45 \mathrm{a}$ \\
& Thiabendazole/thiram & $19 \mathrm{a}$ & $35 \mathrm{~b}$ & $39 \mathrm{~b}$ \\
& Nontreated & $2.5(<0.001)$ & $5.6(0.013)$ & $2(0.001)$ \\
3 & LSD $(P)$ & $2.1 \mathrm{~b}$ & $54 \mathrm{a}$ & $59 \mathrm{a}$ \\
& Thiabendazole/thiram & $12 \mathrm{a}$ & $32 \mathrm{~b}$ & $51 \mathrm{~b}$ \\
& Nontreated & $4.3(<0.001)$ & $4.6(0.021)$ & $2(<0.001)$ \\
& LSD $(P)$ & $18 \mathrm{a}$ & $42 \mathrm{~b}$ & $40 \mathrm{c}$ \\
& Didecyldimethyl-ammonium & & & \\
& chloride & $3.5 \mathrm{~b}$ & $80 \mathrm{a}$ & $56 \mathrm{ab}$ \\
& Thiabendazole/thiram & $2.1 \mathrm{~b}$ & $84 \mathrm{a}$ & $58 \mathrm{a}$ \\
& Fludioxonil & $22 \mathrm{a}$ & $45 \mathrm{~b}$ & $43 \mathrm{bc}$ \\
& Nontreated & $4.7(0.002)$ & $7.2(0.006)$ & $13(0.012)$ \\
\hline
\end{tabular}

${ }^{\mathrm{z}}$ Means followed by the same letter are not significantly different at $P=0.05$.

\section{DISCUSSION}

These experiments have provided new information on the mycoflora associated with pyrethrum seed, the incidence of $P$. ligulicola within pyrethrum seed, identified several fungicide treatments that may reduce seedborne inoculum, and demonstrated a significant relationship between foliar disease intensity during the growing season and incidence of $P$. ligulicola in seed.

Several of the fungi isolated from seed are known to be pathogenic to pyrethrum. For example, $S$. botryosum and A. tenuissima have been characterized as the cause of pink spot and winter blight, respectively. Alternaria alternata, C. cladosporioides, and $U$. atrum have all been confirmed as saprophytes (24). Alternaria spp., Cladosporium spp., and Penicillium spp., have also been associated with pyrethrum seed from India (14). The symptoms associated with disease caused by $P$. ligulicola on mature plants have been well characterized $(23,27)$. However, P. ligulicola has also been associated with seedling damping-off in pyrethrum (S. J. Pethybridge, unpublished data) and damping-off and death of cuttings in chrysanthemum $(4,16)$.

The presence of $P$. ligulicola at incidences up to $28 \%$ in commercial seed lots is of concern. Surface sterilization with sodium hypochlorite reduced the incidence of $P$. ligulicola compared with nonsurface-sterilized seed, but did not eliminate it, suggesting that $P$. ligulicola may be present on both the outer pericarp tissue and within the seed. The failure of surface sterilization to eliminate Alternaria spp., Cladosporium spp., S. botryosum, $U$. atrum, and Microsphaeropsis spp. also suggests their presence both within seed and on the seed surface. Seed infested with P. ligulicola may contribute to primary inoculum for ray blight epidemics. This is consistent with the random distribution of disease in early spring (21) and the occurrence of disease at isolated locations (S. J. Pethybridge, unpublished data). Reductions in seed germination and seedling survival associated with nontreated seed (S. J. Pethybridge, unpublished data) could also reduce field establishment. However, reductions in plant density would lead to a less dense canopy with microclimatic conditions less conducive to disease.

The PCR assay was effective for the detection of seedborne P. ligulicola. Optimization of this assay by the inclusion of BSA in the reaction was able to minimize PCR inhibitors associated with pyrethrum seed and provide more consistent amplification of target DNA fragments. The presence of these inhibitors has been commonly encountered in the development of such assays from a variety of plant substrates (15). The DNA extraction kit by Qiagen was the most reliable for routine detection of $P$. ligulicola in infected seed by PCR. Advantages of PCR over plate tests included reduced assay times, the ability to assess presence in larger subsamples of commercial seed, and alleviated difficulties in detecting $P$. ligulicola among other fast-growing fungi during plate tests. Similar PCR-based assays for the detection of fungal pathogens have been developed for the testing of Leptosphaeria maculans (33), Alternaria brassicae (13), Rhynchosporium secalis (17), Tilletia indica (32), and Alternaria radicina (28).

Several effective measures for reducing the incidence of $P$. ligulicola in seed were demonstrated. Defoliation severity in spring was highly correlated with the incidence of $P$. ligulicola within seed at harvest. Similar relationships have also been found in other pathosystems (12). This finding suggests that the incidence of $P$. ligulicola in seed can be significantly reduced if fungicides are regularly applied to seed fields prior to harvest to reduce disease intensity (25). Furthermore, sites of a higher risk of disease such as those on south facing slopes and in valleys (22) could be avoided for seed production, and sites could be established so they were geographically isolated from commercial fields. Validation of these linear regression models could be useful in the setting of a practical disease intensity threshold during the season, over which the incidence of seedborne $P$. ligulicola is unacceptable. In addition, failing the effective reduction of disease intensity within the field, fungicide seed treatments can be used to protect seeds from fungal infections after planting, or to deter the growth of seedborne fungal pathogens (1). Our trials have demonstrated significant benefits from thiabendazole/thiram and fludioxonil. Thiram has also been demonstrated to be an effective seed treatment in the control of $P$. betae (10). Fludioxonil is a broad spectrum contact fungicide with activity mostly against 
Fusarium spp., although small amounts of this fungicide have been found in internal seed tissues and the coleoptiles of germinating corn seeds (19). Further work is needed to assess the efficiency of these fungicide treatments under a range of field conditions (18). The effectiveness of fungicide alternatives, such as thermotherapy (hot water, hot air, solar heat, aerated steam, and radiation treatment), at eliminating fungal seedborne pathogens has also been recognized, and may prove as effective as fungicides in pathogen control and preserving seed viability $(1,2)$.

Additional studies will quantify the seed to seedling transmission efficiency and therefore the contribution of seedborne $P$. ligulicola to primary inoculum for field epidemics. Further development of treatments to reduce the incidence of $P$. ligulicola associated with pyrethrum seed will also depend upon the significance of this inoculum to field epidemics.

\section{ACKNOWLEDGMENTS}

This work was supported by Botanical Resources Australia Pty. Ltd., Horticulture Australia Limited, the Australian Research Council (LP0211065), and the Pyrethrum Growers Research and Development Committee. We gratefully acknowledge the technical assistance of Roger Latham, University of Tasmania.

\section{LITERATURE CITED}

1. Agarwal, V. K., and Sinclair, J. B. 1997. Principles of Seed Pathology, 2nd ed. CRC Press, Inc., Lewis Publishers, Boca Raton, FL

2. Atanasoff, D., and Johnson, A. G. 1920. Treatment of cereal seeds by dry heat. J. Agric. Res. (Washington D.C.) 18:379-390.

3. Baker, K. F., Dimock, A. W., and Davis, L. H. 1949. Life history and control of the Ascochyta ray blight of chrysanthemum. Phytopathology 39:789-805.

4. Baker, K. F., Dimock, A. W., and Davis, L. H. 1961. Cause and prevention of the rapid spread of the Ascochyta disease of chrysanthemum. Phytopathology 51:96-101.

5. Barnett, H. L. 1965. Illustrated Genera of Imperfect Fungi. Burgess Life Science Series, Burgess Publishing, Minneapolis, MN.

6. Blakeman, J. P., and Hornby, D. 1966. The persistence of Colletotrichum coccoides and Mycosphaerella ligulicola in soil, with special reference to sclerotia and conidia. Trans. Br.
Mycol. Soc. 49:227-240.

7. Boerema, G. H., de Gruyter, J., Noordeloos, M. E., and Hamers, M. E. C. 2004. Phoma Identification Manual. Differentiation of Specific and Intra-specific Taxa in Culture. CABI Publishing, Egham, Surrey, UK.

8. Chesters, C. G. C., and Blakeman, J. P. 1966. The survival on chrysanthemum roots of epiphytic mycelium of Mycosphaerella ligulicola. Ann. Appl. Biol. 58:291-298.

9. Chesters, C. G. C., and Blakeman, J. P. 1967. Host range and variation in virulence of $M y$ cosphaerella ligulicola. Ann. Appl. Biol. 60:385-390.

10. Durrant, M. J., Payne, P. A., Prince, J. W. F., and Fletcher, R. 1988. Thiram steep seed treatment to control Phoma betae and improve the establishment of the sugar-beet plant stand. Crop Prot. 7:319-326.

11. Gibbs, A. J., and Gower, J. C. 1960. The use of a multiple transfer method in plant virus transmission studies - Some statistical points arising in the analysis of results. Ann. Appl. Biol. 48:75-83.

12. Glenn, D. L., Phipps, P. M., and Stipes, R. J. 2003. Incidence and survival of Cylindrocladium parasiticum in peanut seed. Plant Dis. 87:867-871.

13. Guillemette, T., Iacomi-Vasilescu, B., and Simoneau, P. 2004. Conventional and real-time PCR-based assay for detecting pathogenic $\mathrm{Al}$ ternaria brassicae in cruciferous seed. Plant Dis. 88:490-496.

14. Janardhanan, K. K., and Ganguly, D. 1963. Fungal flora of seeds of some important medicinal plants. Indian Phytopathol. 16:379-381.

15. Jobes, D. V., Hurley, D. L., and Thien, L. B. 1995. Plant DNA isolation: A method to efficiently remove polyphenolics, polysaccharides, and RNA. Taxon 44:379-386.

16. Judd, R. W., Jr., and Walton, G. S. 1973. Benomyl dip for the control of Ascochyta decay of chrysanthemum cuttings. Plant Dis. Rep. 57:624.

17. Lee, H. K., Tewari, J. P., and Turkington, T. K. 2001. A PCR-based assay to detect Rhynchosporium secalis in barley seed. Plant Dis. 85:220-225.

18. McGee, D. C. 1981. Seed pathology: Its place in modern seed production. Plant Dis. 65:638642.

19. Munkvold, G. P., and Shriver, J. M. 2000. Evaluation of seed treatment fungicides for corn, 1999. Fungic. Nematicide Tests 55:432.

20. Nutter, F. W., Jr., and Schultz, P. M. 1995. Improving the accuracy and precision of disease assessments: Selection of methods and use of computer-aided training programs. Can. J. Plant Pathol. 17:174-184.

21. Pethybridge, S. J., Esker, P., Hay, F. S., Wilson,
C. R., and Nutter, F. W., Jr. 2005. Spatiotemporal description of epidemics caused by Phoma ligulicola in Tasmanian pyrethrum fields. Phytopathology 95:648-658.

22. Pethybridge, S. J., and Hay, F. S. 2001. Influence of Phoma ligulicola on yield and site factors on disease development in Tasmanian pyrethrum crops. Aust. Plant Pathol. 30:17-20.

23. Pethybridge, S. J., Hay, F. S., and Groom, T. 2003. Seasonal fluctuations associated with pyrethrum foliage in Tasmania. Aust. Plant Pathol. 32:223-230.

24. Pethybridge, S. J., Hay, F. S., and Wilson, C. R. 2004. Pathogenicity of fungi commonly isolated from foliar disease in Tasmanian pyrethrum crops. Aust. Plant Pathol. 33:441-444.

25. Pethybridge, S. J., Hay, F. S., Wilson, C. R., and Groom, T. 2005. Development of a fungicide-based management strategy for foliar disease caused by Phoma ligulicola in Tasmanian pyrethrum fields. Plant Dis. 89:1114-1120.

26. Pethybridge, S. J., Scott, J. B., and Hay, F. S. 2004. Genetic relationships among isolates of Phoma ligulicola from pyrethrum and chrysanthemum based on ITS sequences and its detection by PCR. Aust. Plant Pathol. 33:173-181.

27. Pethybridge, S. J., and Wilson, C. R. 1998. Confirmation of ray blight disease of pyrethrum in Australia. Aust. Plant Pathol. 27:4548.

28. Pryor, B. M., and Gilbertson, R. L. 2001. A PCR-based assay for detection of Alternaria radicina on carrot seed. Plant Dis. 85:18-23.

29. Punithalingam, E. 1980. Didymella chrysanthemi, CMI Descriptions of Pathogenic Fungi and Bacteria, No. 662. Kew, UK.

30. Robinson, R. A. 1963. Diseases of pyrethrum in Kenya. East Afr. Agric. For. J. (January) 164-167.

31. Shaw, D. E. 1984. Micro-organisms in Papua New Guinea. Department of Primary Industry, Res. Bull. No. 33, Port Moresby.

32. Smith, O. P., Peterson, G. L., Beck, R. J. Schaad, N. W., and Bonde, M. R. 1996. Development of a PCR-based method for identification of Tilletia indica, causal agent of Karnal bunt of wheat. Phytopathology 86:115-122.

33. Taylor, J. L. 1993. A simple, sensitive and rapid method for detection of seed contaminated with highly virulent Leptosphaeria maculans. Appl. Environ. Microbiol. 59:36813685 .

34. Van der Aa, H. A., Noordeloos, M. E., and De Gruyter, J. 1990. Species concepts in some larger genera of the Coelomycetes. Studies Mycol. 32:3-19.

35. Walker, J., and Baker, K. F. 1983. The correct binomial for the chrysanthemum ray blight in relation to its geographical distribution. Trans. Br. Mycol. Soc. 80:31-38. 